\title{
The Effect Of Using Small Group Discussion On The Second Grade Students' Speaking Skill
}

\section{Hendra Suryadi}

\begin{abstract}
Speaking is one of the main purposes of language learning in that it is an ability to transfer some ideas to other people clearly and correctly. In other words, he or she can communicate his or her ideas well to other people. As speaking dominates all activities in the English subject, the language components, namely pronunciation, fluency and vocabulary should also be learnt to support the language skills. Based on the English teacher interview result that small group discussion have never been used by the teachers, speaking skill on the eighth grade students of junior high school of SMP Darul Muhajirin, so it was necessary to conduct a research in this school. The research design was quasi experimental. It began from conducting homogeneity test, deciding the experimental class and the control class, giving activities to the control class using the common technique and material usually applied by the English teacher and treatments to the experimental class that was using small group discussion in teaching speaking, then giving the same post-test to both classes, and the last analyzing the results of the post-test by using t-test. The result of this research The analysis of the post test results showed that there was a significant effect of using small group discussion that of speaking skill the experimental class got higher mean score than the control class $(65,1>57,5)$ of the students' speaking skill. Then, the result of data analysis using SPSS showed that the t-test value (2-tailed) 0.000 , was less than 0.05.is expected to provide useful information for the English teacher to use interesting materials, that is, small group discussion in the English teaching learning process, especially in teaching speaking, since the small group discussion have never been used at SMPN Darul Muhajirin.
\end{abstract}

Key Words: Small Group Discussion, Speaking Skill.

\section{INTRODUCTION}

Language is a system for the expression of meaning. Its primary function it for interaction and communication (Mcdonough \& Shaw, 2003).Language is used by human in order to know and understand each other. As we know that good created human in different human, characters, culture and country, so they need to interact among people.

English is used by millions of people over the world. In Indonesia, English is considered as foreign language or target language that has been taught from Elementary school up to the university. In education aspect, the students hopefully be able to speak English fluency in order that the can compete in the technology government.

In learning language there are four skills should be mastered in among, Listening, Speaking, Reading and writing. Speaking is one of the important skill besides them. Speaking is an activity used by someone to communicate with others. It takes place everywhere and has become part of our daily activities. When someone speaks, he or she interacts and uses the language to express his or her ideas, feeling and thought. He or she also shares information with others through communication.

Speaking skill is partly a reflection of someone whether he/she masters this language or not. Speaking is one of the main purposes of language learning in that it is an ability to transfer some ideas to other people clearly and correctly. In other words, he or she can communicate his or her ideas well to other people.

In teaching and learning English as the foreign language most students cannot speak English well. For that condition, there are some factors of the difficulties. Those are, internal and external factors. Internal factors come from the students themselves. These concern with personality factors. The students were afraid to express their ideas, they worried everyone will 
mock them. Other factors come out from students. This concern with their environment, parents, association, and teaching learning technique in their school. Teaching and learning technique is the important factor to the success of language learning for all aspect in education. But for the fact, the teacher does not choose the suitable technique in teaching speaking. She taught them by asking the students to read the dialogue or book in front of the class. These activities did not give any opportunity to express their idea directly. So students can not improve their speaking skill by teaching learning process.

Based on the result of interview with the English teacher of MTs Darul Muhajirin on $17^{\text {th }}$ march 2020 the teacher said "the students' had some difficulties when they were learning English especially speaking, this is happened because when the teacher ask the students' to present in front of the class, many of the students' fell nervous and afraid of making a mistake and also the students' have lack confidents to speak/express their idea in front of the class because they felt worried if their friends will laugh of their mistakes". After the researcher know the problems that face by the researcher, the researcher given of the appropriate method that can be used for make the students' speaking better than before, the method name is Small Group Discussion. The researcher hopes this method can make the students' more confidents to express their opinion, idea and suggestion with their friends by using this small group discussion.

Based on the explanation above, the researcher is interested to conducting the research entitled "The Effect of Using Small Group Discussion on the Second Grade Students' Speaking Skill'.

Speaking Skill

Speaking is one of the important skill should be mastered in process learning English language. Webster, (1972) speaking means as the act, utterance, or discourse of one who speak. White as verb (speak) is to utter word act or articulate sounds with the ordinary voice, to take or exercise the faculty of speech, to make oral communication or mention as to speak to someone to various matter, to converse "as they speak for hours on the phone".

Clark and Clark, (1997) state that speaking is "a complex skills, required the simultaneous of number of different abilities which often developed different late either four or five competences, are generally reconquered in analysis is of speeches process, there are including as the entering system, pronunciation, grammar, vocabulary, fluency and comprehension".

Bygate (1997: vii) believes that speaking is in many ways an undervalued skill. Perhaps this is because we can almost all speak, and so take the skill too much for granted. Speaking is often thought of as a 'popular' form of an expression which uses the unprestigious 'colloquial' register: literacy skills are on the whole more prized. This relative neglect many perhaps also be due to the fact that speaking is transient and improvised, and can therefore be viewed as facile, superficial, or glib.

Mackey (2001: 79) defines that speaking is an oral expression that involves not only the use of right patterns of rhythm and intonation but also right order to convey the right meaning.

While Thornbury (2005: IV) says that speaking is an interactive and requires the ability to cooperate in the management of speaking turn.

Based on the expert speaking can be described that speaker first plan what they want to say based on how to change the mental state of their listener, then they put their plan into execution, uttering the segments, words, phrases and sentence that make up the plan. But, it is not a simple as we know and think, because speaking in this case, is speaking English with a lot of rules, such as pronunciation, intonation, fluency, tone of voice, stress, structure, choice of words and effectiveness of communication.

Group Discussion 
According to Hoover (1997:13), discussion is the process of talking things over among two or more persons, preferably face to face. He adds that the total discussion process ideally is a cooperative effort on the part of a number of individuals to work together as a group, through the exchange of thought orally, toward some group objectives. Risk states that "discussion means thoughtful consideration of the relationship involved in the topic or problem under study". Ur (1997:2) says that thinking out some problems and situations together through verbal interchange of ideas is simply called as to discuss. From those definitions, it can be concluded that discussion is the exchange of information, opinion, and ideas.

Small Group Discussion

Small group discussion is a cooperative learning method which gives more opportunities to students in gathering their ideas, experience, knowledge, and actualizing in speaking. Hence, the teacher should have a good maturity to be able to support his/her students in order to carry out the teaching learning process well. It's related to Kelly and Stafford (1993) stated "in order to prepare effectively for a series of discussion sessions, teachers need a good appreciation of the level that students have reached, based on their previous experience and the value of the institution in which the work will occur".

Kidsvatter (1996:242) states that a small-group discussion dividing the large classroom into small groups of students to achieve specific objectives permits students to assume more responsibility for their own learning, develop social and leadership skills and become involved in an alternative instructional approach.

Slavin E. Robert, (1995) states, cooperative learning refers to a variety teaching method in which students work in small group to help one another academic content. Cooperative work replaces teacher instruction, and then it replaces individual seatwork, individual study and individual drill. When properly organized, students in cooperative group work each other to make certain that everyone in the group has mastered the concept being taught

In other word, cooperative learning (CL) empowers students in teaching learning process in classroom because each member of the team is responsible for their term's successful

\section{RESEARCH METHOD}

Research Design

The design that was used in this research was quasi experimental research design, with nonequivalent group posttest-only design (McMillan, 1992:175). It was intended to know whether or not the use of Small Group Discussion on speaking skill I experimental group. The design of this research was described as follows:

$\begin{array}{lll}\text { K1 } & \text { X } & \text { T1 } \\ \text { K2 } & \text { O } & \text { T1 }\end{array}$

Notes:

K1: The experimental Class

$\mathrm{K} 2$ : The control Class

$\mathrm{X}$ : Treatment

O: No treatment (common way/using text books)

T1: Post-Test (Speaking Skill test)

(Adapted from Setiyadi, 2006:142)

The procedures of this research were as follows:

1. Conducting the homogeneity test.

2. Analyzing the scores of homogeneity test using ANOVA (Analysis of Variance). The value of variance was significant (less than 0.05) which means that the population was heterogeneous, so, two classes from the population which had the closest mean score were chosen. They were class VIII A and class VIII B

3. Deciding the experimental class and the control class by lottery.

4. Giving the treatment to the experimental class that was, teaching Speaking skill by using Small Group Discussion (speech context ), while the control class was taught 
speaking skill by using textbooks as the English teacher of the eighth grade students usually uses.

5. The teaching learning process was conducted in two meetings; each meeting was conducted in 80 minutes.

6. Administering try out test to establish reliability and validity of the teacher-made test. The try out was given to class VIII C as this class had the closest mean score to the control class and the experimental class.

7. Administering Speaking skill post-test to both classes to know the result of the experimental treatment given with 20 test items in 60 minutes.

8. Applying the independent sample t-test formula to find out the mean difference of both classes.

9. . 9. Comparing the results of the speaking test between the control class and the experimental class to know the significant mean difference to find the effect of the use of small group discussion on the eighth year students' speaking skill.

10. Drawing a conclusion from the results of the data analysis to answer the research problem. The area of the research was SMPN Darul Muhajirin. This school was determined purposively.

In the purposive method, the researcher selects particular elements from the population that will be representative or informative about the topic (Mc Millan, 1992:76). Cluster random sampling was one kind of sampling procedure that was used in this research. According to Setiyadi (2006:42), cluster random sampling is taken when the population has several different groups and the groups are not a stratum. Since the result of the homogeneity test showed that the population was heterogeneous, two classes that had the closest mean score were taken and determined to be the experimental class the control class by using lottery. There were two kinds of data that were used in this research; they were primary data and secondary data. The primary data were the students' scores of speaking skill test. Then, the supporting data were the results of the interview (with the English teacher of the eighth grade students as the interviewee) and the school documents of the grade VIII students at SMP Darul Muhajirin in academic year 2019/2020. Djiwandono (1996:22-23) states that there are two kinds of test used to measure the students' achievement; they are teacher made test and standardized test. The test that was used in this research, was teacher made test in the form of objective test and subjective test for the exercises and speaking skill test as the post test. In this research, the post test was used in this research to measure the speaking skill after the treatment was given to the experimental class was taught speaking by using small group discussion and the control class was taught speaking by using textbook. Interview with the English teacher of the eighth grade students was conducted to know the techniques/methods of teaching or the media used by the English teacher in teaching speaking. In this research, the informal interview was done with the English teacher to get the information needed to complete the main data. During the interview, a list of questions related to the information needed were used as the interview guide. Documentation is one method that is used to support the primary data. Setiyadi (2006:249) states that documentation is natural data source that is easy to get, it could be private or formal data. In this research, documentation was used to get the supporting data about the respondents' names from both of the experimental class and the control class. PostTest Only Control class Design was used in this research. Setiyadi (2006:142) claims that PostTest Only Control class Design is a kind of research design that uses two classes. The first class was called as an experimental class and the second was a control class. This design was used to compare the mean score of the experimental class that was taught speaking by using small group discussion and the mean score of the control class that was taught 
speaking by using the reading materials taken from the textbooks.

\section{RESEARCH FINDINGS AND DISCUSSIONS}

To support the primary data, the supporting data were obtained through the interview with the English teacher and documentation. The interview was conducted with the English teacher of the eighth grade students. The eighth grade students were divided into 3 classes, VIII A, VIII B, and VIII $\mathrm{C}$ was different from the other classes because it was a superior class in English ability, therefore it was excluded. The curriculum used for the eighth grade students of SMPN Darul Muhajirin was Institutional Based Curriculum. According to the English teacher, the English lesson was taught twice a week, students got difficulty in speak up in front of the class. The English teacher only taught the material from the textbook, and he or she had never used the small group discussion. The Documentation was used to get the supporting data about the respondents and the total number of the eighth grade students of SMPN Darul Muhajirin in Academic year 2019/2010., The total number of the eighth grade students of SMPN Darul Muhajirin in Academic year 2019/2010 was 95 students that were divided into three classes as mentioned above.

The homogeneity test was conducted to all classes (except VIII A) because VIII A was considered as a special and a superior class which had different English ability from the other classes. It was conducted on September 26th 2019. This schedule was consulted to the English teacher, vice headmaster for curriculum and some teachers for using their teaching periods to conduct the homogeneity test. The try out was administered on October $1^{\text {st }} 2019$. It was given to neither the experimental class nor the control class; it was given to class VIII C. The try out was conducted to find out the test validity, the reliability coefficient, and the difficulty index of the test items. The results of the main data were the results of the post-test given after the small group discussion of the control class and the treatments given to the experimental class. The post test was administered on Oktober 6th to get the data about the significant difference between the experimental and the control classes. The experimental class had the higher mean score that was 65,1 , while the mean score of the control class was 57, 4. From the result of the independent sample t-test, the mean score of the post-test of the experimental class was 71.7647 and the mean score of the post-test of the control class was 1.665. Then the result of data analysis was consulted to the t-table of $5 \%$ significance level (confidence interval 95\%) to know whether the result was significant or not. Based on the output of Independent sample ttest by using SPSS software, the value of Levene's Test of Equality variances was 0.486. The variability of the experimental class and the control class was equal (Levene's test significance level was greater than 0.05). It means there was a significance effect on the eighth grade students' speaking skill by using small group discussion. Based on the output of independent t-test by using SPSS, the value of significant column was 0,000 and it was lower than 0.05 . It could be said that the hypothesis which says "There is a significant effect of using small group discussion on the eighth grade students speaking skill at SMPN Darul Muhajirin" was accepted. The analysis of the post test results showed that there was a significant effect of using small group discussion on the students' speaking skill in the speaking test. The experimental class got higher mean score than the control class $(65,1>57,5)$. Then, the result of data analysis using SPSS showed that the t-test value (2-tailed) 0.000, was less than 0.05., that was 0, 486. The previous research done by Lalu Bohari (2019). Improving Speaking Skills Through Small Group Discussion at Eleventh Grade Students of SMA Plus Munirul Arifin NW Praya Comparing to the previous research, there were some similarities and differences. The first 
similarity was both the researchers used Small Group Discussin as the source of texts. The second similarity was both of dependent variables focused on the students' Speaking Skill. On the other side there were differences between the previous research and this research. Lalu Bohari Chose senior high school students as the population but the population of this research was junior high school students. From the discussion above, it could be concluded that there was a significant effect of using Small Group Discussion on the eighth grade students' speaking skill in SMP Darul Muhajirin. It means that the experimental class that was taught speaking by using small group discussion got better scores in the speaking post-test than the control class that was taught reading by using textbooks.

\section{CONCLUSIONS AND SUGGESTIONS}

The result of the data analysis showed that the statistical value of significance column was lower than 0.05. $(0,486)$ It could be concluded that the use of small group discussion had a significant effect on the eighth grade students' speaking skill at SMP Darul Muhajirin in Academic year 2019/2020. Based on the research result above, some suggestions are given to the English teacher, the students, and the other researchers 1. It is suggested to the English teachers of SMPN Darul Muhajirin to use the small group discussion in teaching the students' speaking skill because they were interesting and motivating. 2. The students of SMPN Darul Muhajirin are suggested to enhance their speaking skill by practice speaking using small group discussin related to the materials. 3. The other researchers in the future are suggested to use the research result as information or input to conduct a further research with different research design as such as a class action research to improve the students' speaking skill by using small group discussion such as speec

\section{REFERENCES}

Bygate, M. (1997). Speaking. New York: Oxford University Press.
Clark and Clark. (1997). Psychology and Language. New York: Harcourt Brace Jovanovich Inc, P.17.

Djiwandono, M.S. (1996). Tes Bahasa dalam Pengajaran. Bandung: ITB.

Johshon, K and Morrow, K. (1997). Communication in the Classroom. London: Longman, P.17

Kelly and Stafford. (1993), Managing Small Group Discussion. Workshop Series No.9, P.3.

Kidsvatter, R. (1996). Dynamics of effective teaching. London: Longman Published Ltd.

Mcdonough, Jo \&Christopher Shaw. (2003). Materials and Method in ELT: A Teacher's Guide, $2^{\text {nd }}$ Ed. UK: Blackwell Publishing.

McMillan. (1992). Educational Research: Fundamentals for Consumer. New York: Harper Collin Publisher.

Setiyadi, B. (2006). Metode Penelitian Untuk Pengajaran Bahasa Asing Pendekatan Kuantitatif dan Kualitatif. Yogyakarta: Graha Ilmu.

Slavin, E. Robert. (1995). Cooperative Learning Teory: Research and Practice. New York: The Hopkins University, P.2.

Thornbury, S. (2005). How to Teach Speaking. New York: Pearson Education Inc.

Ur, P. (1994). Discussion that work-taskcentered fluency practice. London: Cambridge University Press.

Webster. (1972). Webster's New World Collage Dictionary. New York: Then World Publishing Company, P.684. 